\title{
Pollution-toxicity relationships in sediments of the Segura River Basin
}

\author{
Javier García-Alonso ${ }^{1,2, *}$, Julio Gómez ${ }^{3,4}$, Francisco Rafael Barboza ${ }^{3,4}$ and Francisco José \\ Oliva-Paterna $^{5}$
}

${ }^{1}$ Faculty of Science, University of Hull, Hull HU6 7RX, United Kingdom.

${ }^{2}$ Biodiversity Group, Centro Universitario de la Región Este, Universidad de la República, 20000, Maldonado, Uruguay.

${ }^{3}$ UNDECIMAR, Facultad de Ciencias, Universidad de la República, Montevideo, 11400, Uruguay.

${ }^{4}$ GEPEIA, Centro Universitario de la Región Este, Universidad de la República, Ruta nacional $\mathrm{N}^{\circ} 9$ intersección con Ruta No 15, Rocha, Uruguay.

${ }^{5}$ Departamento de Zoología y Antropología Física, Universidad de Murcia, Murcia, 30100, Spain.

*Corresponding author: jgalonso@cure.edu.uy

Received: 22/04/2013 Accepted: 12/12/2014

\begin{abstract}
Pollution-toxicity relationships in sediments of the Segura River Basin

River basins are characterised by their geomorphology and the water flow of the catchment area and, therefore, the transport and fate of materials suspended and dissolved in the water. In this context, the distribution of pollutants in a river is expected to be determined by the different uses of the soil and the environmental characteristics of the basin. Thus, integrative approaches that consider the causes (pollutants) and effects (toxicities) of anthropogenic impacts and take into account the environmental particularities of a basin are vital for generating appropriate mitigation and management plans for specific sites. Here, we analysed the association between sediment concentrations of trace metals and endocrine disrupting compounds (EDCs) with sediment toxicity levels (genotoxicity) at different altitudinal points of the Segura River Basin. The highest levels of chromium, lead, zinc, nickel and copper, as well as EDCs, were found in downstream points near Orihuela city. Toxicity was positively correlated with most of the pollutants and negatively correlated with the altitude. Due to flow reduction in plain areas, high pollutant concentrations and toxicities were observed in lowlands, where most of the contaminant inputs and accumulations occur.
\end{abstract}

Key words: Multivariate analysis, metals, EDCs, sediment toxicity.

\section{RESUMEN}

\section{Relación contaminación-toxicidad en sedimentos de la cuenca del Río Segura}

Las cuencas hidrográficas se caracterizan por su geomorfología, caudal y área de drenaje, lo que en consecuencia determina el transporte y destino de los materiales suspendidos y disueltos en la columna de agua. En este contexto, se espera que la distribución de contaminantes en la cuenca de un río esté determinada por distintos usos de suelo, existiendo un gradiente de acumulación de estos compuestos en dirección aguas abajo. Así, el desarrollo de aproximaciones integradoras que consideren las causas (contaminantes) y los efectos (toxicidades) de los impactos antropogénicos teniendo en cuenta las particularidades ambientales de la cuenca, son extremadamente necesarias para permitir la generación de planes de mitigación y manejo sitioespecíficos. En el presente estudio se analizó la asociación entre la concentración de metales traza y compuestos disruptores endocrinos orgánicos (EDCs) con los niveles de toxicidad (genotoxicidad) en sedimento en distintos puntos altitudinales de la cuenca del Río Segura. Los mayores niveles de cromo, plomo, zinc, níquel y cobre, así como de EDCs se encontraron aguas abajo en las cercanías de la ciudad de Orihuela. Los resultados obtenidos muestran que la genotoxicidad está positivamente correlacionada con la concentración de contaminantes y negativamente con la altitud. Debido a la disminución del flujo de agua en zonas más bajas, se observó una mayor acumulación de contaminantes y un aumento de la toxicidad hacia la desembocadura del Río Segura, donde se produce el mayor ingreso de compuestos de origen antropogénico a la cuenca.

Palabras clave: Análisis multivariante, metales, disruptores endocrinos, toxicidad en sedimentos. 


\section{INTRODUCTION}

In river basins, water flow transports dissolved chemicals and suspended sediments, which accumulate in the sediments of downstream areas. In addition, urbanisation and industries are historically settled in low-plain areas. Therefore, the main sources and fates of chemical pollutants are generally located in lowland regions (Luoma \& Rainbow 2008).

Some metals and endocrine disrupting chemicals (EDCs) at certain concentrations in water or sediments produce toxic effects in aquatic biological communities. Metals such as cadmium $(\mathrm{Cd})$, chromium $(\mathrm{Cr})$, cobalt $(\mathrm{Co})$, lead $(\mathrm{Pb})$, nickel $(\mathrm{Ni})$, copper $(\mathrm{Cu})$, zinc $(\mathrm{Zn})$ and the metalloid arsenic (As) are elements that accumulate in the sediments of watersheds and estuaries and have biological consequences, e.g., inducing DNA damage or genotoxicity, oxidative stress and increased permeability in the blood-organ barriers (Norris \& Carr, 2006). Some metal ions can bio-accumulate in animal tissues and biomagnify through the food chain, with potential effects on human health (Luoma \& Rainbow, 2008). The EDCs, nonylphenol (NP), octylphenol (OP) and bisphenol A (BPA) are well-known persistent pollutants with estrogenic activity that affect normal physiological processes (e.g., dysfunctional reproductive effects) in vertebrates and invertebrates. Although they are banned in Europe, their concentrations remain elevated in aquatic environments (Cooper \& Kavlock, 1997; Nice et al,. 2003; Janex-Habibi et al,. 2009; García-Alonso et al., 2011).

Located in south-eastern Spain, the Segura River Basin represents one of the most semiarid areas of Europe, and its fluvial network includes sparsely populated forested headwaters, populated agricultural midlands and densely populated cities in the lowlands (Vidal-Abarca, 1990; Velasco et al., 2003; Mellado et al., 2008). Most of the river basin is used for agriculture (Veses $e t$ al., 2013). Despite its small size $\left(18870 \mathrm{~km}^{2}\right)$, it shows dramatic climatic and altitudinal gradients from NW to SE (Sánchez-Montoya et al., 2007; Belmar et al., 2011). Despite some recent works

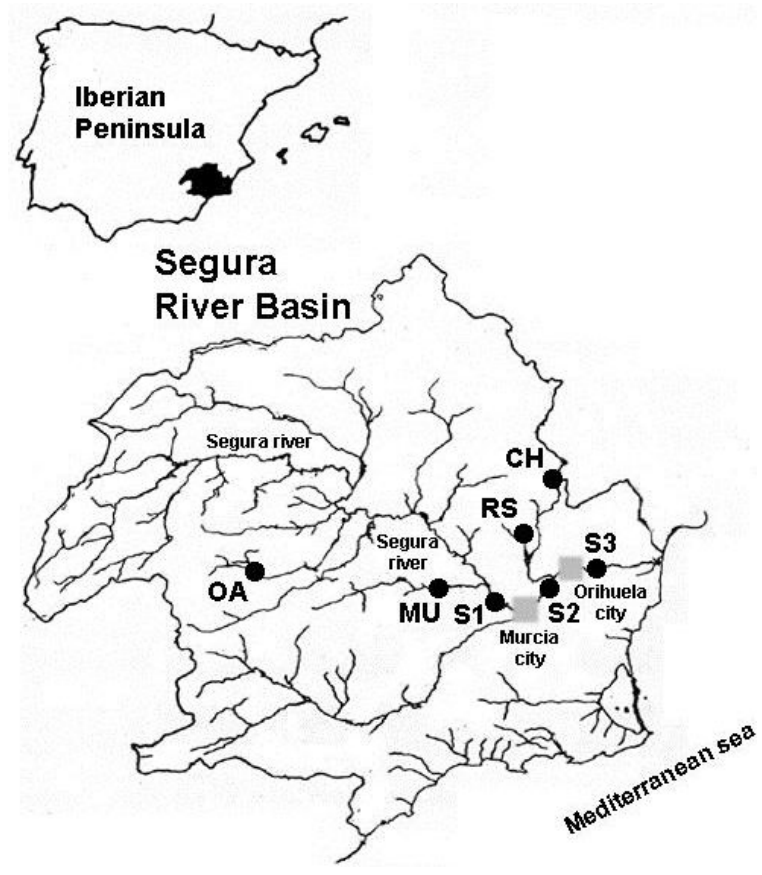

Figure 1. Sampling points in the Segura River Basin. OA, Ojos de Archivel; CH, Chícamo stream; RS, Rambla Salada stream; MU, Mula stream; S1, S2 and S3 are located on the main Segura River. Location of the cities of Murcia and Orihuela are indicated (grey squares). Puntos de muestreo en la Cuenca del río Segura. OA, Ojos de Archivel; $\mathrm{CH}$, río Chícamo; $R S$, rambla Salada; $M U$, río Mula; S1, S2 y S3 están localizados en el propio río Segura. Se presenta la ubicación de las ciudades de Murcia y Orihuela (rectángulos grises).

showing high concentrations of $\mathrm{Cr}$ in the water and sediments of the river, little effort has been made to analyse the concentrations or distributions of pollutants or their relationships with toxicities in the Segura River (see Veses, et al. 2013). Such information, combined with the environmental characteristics (or variables representing their variation, such as altitude) of the basin analysed using multivariate approaches, will constitute a critical input to guarantee the sustainable use and management of ecosystems goods and services provided by the Segura Basin. In this sense, the main goal of this work was to describe and analyse the concentrations of trace metals and EDCs in the sediments of the Segura River at locations ranging from putatively pristine to urban and industrial stations. The information concerning pollutants was correlated with the genotoxicities and altitudes of the sampling 
sites through a multivariate approach, giving us the opportunity to determine the areas of chemical accumulation and high toxicities for humans and the resident biota.

\section{MATERIALS AND METHODS}

\section{Sampling procedure}

The Segura River Basin covers a drainage area of approximately $18870 \mathrm{~km}^{2}$ (Fig. 1). The basin contains several dams and reservoirs that change the flow of the main river and tributaries (Belmar et al., 2010 and 2011). The basin exhibits several semiarid ecosystems that include different habitat types, and it has high biodiversity and a variety of animals vulnerable to anthropogenic impacts (Velasco et al., 2003; Gómez et al., 2005). These systems present a wide range of environmental conditions, including both extremely low and high conductivities (Vidal-Abarca et al., 2002; Mellado et al., 2002; Sánchez-Montoya et al., 2007). However, since 1979, the Tajo-Segura river diversion has brought water for irrigation; as a consequence, the ecological status of several streams in the basin has decreased (VidalAbarca, 1990). In general, the basin sediments consist of deposits of gravels and sand in the erosional zones of runs and silts in the pools and depositional zones (Bonada et al., 2002).

The sampling locations considered in the study (Fig. 1) covered an altitudinal range from 29 to $434 \mathrm{~m}$ (Table 1). Four sampling sites (Ojos de Archivel, OA; Chícamo, CH; Mula, MU; and Rambla Salada, RS) are located in the middle catchment tributaries, and the sampling sites located in the main channel of the Segura River are upstream of Murcia City (S1), immediately downstream of Murcia City (S2) and downstream of the city of Orihuela (S3). Three replicates per sampling site were taken. Surface sediments $(10 \mathrm{~cm})$ were obtained with a soil corer in a water depth of $10 \mathrm{~cm}$ at the bank of the river and in areas where sediment accumulates. Samples were collected in glass flasks and stored in the dark at $-20{ }^{\circ} \mathrm{C}$ (University of Murcia), dried at $50{ }^{\circ} \mathrm{C}$ and cooled-transported in thermo boxes to the Analytical Laboratory (University of Hull). Organic matter contents in the sediments were measured as percentage loss on ignition (dried sediment maintained at $550{ }^{\circ} \mathrm{C}$ for $3 \mathrm{~h}$ ).

\section{Metal analysis}

The quantification of metals and the metalloid arsenic (As) was performed as described previously (García-Alonso et al., 2011). Sediment samples were dried at $60{ }^{\circ} \mathrm{C}$ for 24 hours, ground and sieved, and then, $1 \mathrm{~g}$ of each sample was taken for extraction. Dry samples were weighed to $0.1 \mathrm{mg}$ accuracy and extracted in $55 \mathrm{ml}$ PFA Teflon digestion vessels with $10 \mathrm{ml}$ of nitric acid $\left(\mathrm{HNO}_{3}\right)$, avoiding the extraction of metals bound to silica, which were assumed to not be bioavailable. The sealed vessels were loaded into the microwave digestion system (MARS Xpress, CEM Corp, Matthews NC, USA), heated to $200{ }^{\circ} \mathrm{C}$

Table 1. Category and environmental characterisation of each sampling site. Locality codes, altitude, habitat type, ecological status and physicochemical parameters are shown. Denominación y caracterización ambiental de cada localidad de muestreo. Se presentan el código de la localidad, altitud, tipo de hábitat, estado ecológico, y parámetros físico-químicos.

\begin{tabular}{lcccccc}
\hline Locality & Sampling site Code & Altitude $(\mathrm{m})$ & Habitat & Ecological status $(*)$ & $\mathrm{pH}(* *)$ & Organic matter \\
\hline Ojos de Archivel & OA & 434 & Creek & 1 (Good) & 8.0 & $7.7 \pm 0.2$ \\
Chícamo & CH & 306 & Stream & 1 (Good) & $(7.8-8.3)$ & $34.1 \pm 0.2$ \\
Mula & MU & 283 & Stream & 3 (Defficient) & $(8.0-8.3)$ & $10.6 \pm 0.3$ \\
Rambla Salada & RS & 143 & Stream & 2 (Moderate) & $(7.8-8.4)$ & $21.3 \pm 1.1$ \\
Segura upstream Murcia & S1 & 63 & Main River & $4(\mathrm{Bad})$ & $(8.1-8.3)$ & $16.2 \pm 0.2$ \\
Segura downstream Murcia & S2 & 36 & Main River & $4(\mathrm{Bad})$ & $(8.1-8.3)$ & $17.9 \pm 0.1$ \\
Segura downstream Orihuela & S3 & 29 & Main River & $4(\mathrm{Bad})$ & $(8.1-8.3)$ & $23.7 \pm 1.0$ \\
\hline
\end{tabular}

(*) Ecological status in accordance with the Water Framework Directive.

(**) Data from Mellado et al., (2002). 
for 15 minutes and then left to cool to room temperature. The digests were then analysed using the Optical Emission Spectrometer (Optima 5300DV, Perkin Elmer, Shelton, CT, USA). A reference digest of sediment (Greyhound, \# CRM-ES) was analysed with the samples and produced the expected concentrations of 8 metals (As, $\mathrm{Cd}, \mathrm{Co}, \mathrm{Cr}, \mathrm{Cu}, \mathrm{Pb}, \mathrm{Zn}$ and $\mathrm{Ni}$ ). The metals of interest were then analysed quantitatively against 4 calibration standards that had been freshly prepared from certified single elements (Romil Ltd.). As, $\mathrm{Cd}$ and $\mathrm{Pb}$ were measured in axial view mode, while the other elements were measured in radial view mode. Three replicates of each measurement were performed, and blank solutions $\left(2 \% \mathrm{HNO}_{3}\right.$ in distilled deionised water) were used to calculate the detection limits of the experiment, defined as 3 times the standard deviation of the mean of 13 blanks.

\section{Organic pollutants analysis}

All the steps were performed in acetone-washed glass materials. Samples were spiked with $100 \mu \mathrm{l}$ of internal standard ([13C6]-363 NP). Organic fractions were extracted from sediments (sieved fraction $<100 \mu \mathrm{m}$ ) using a Soxhlet apparatus. Five grams of sediment was poured into a $41 \times 123 \mathrm{~mm}$ cellulose thimble (Whatman) and extracted with $90 \mathrm{ml}$ of hexane:isopropanol (85:15, v:v) over 6 hours at $60^{\circ} \mathrm{C}$. After evaporation and drying under a stream of nitrogen, the samples were re-dissolved in $200 \mu$ of acetone and derivatised with $25 \mu \mathrm{l}$ of MSTFA at room temperature. Analyses were carried out using an Agilent 6890N gas chromatograph (GC) directly connected to an Agilent 5973 inert mass selective detector (MS) as described by Ayoola et al., (2010) with some modifications. Briefly, $1 \mu \mathrm{l}$ per sample was injected into the GC-MS in selective ion mode (SIM) at a flow rate of

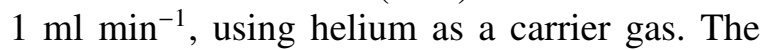
temperature programme was held at $60^{\circ} \mathrm{C}$ for 1 minute and then increased to $280^{\circ} \mathrm{C}$ for $10^{\circ} \mathrm{C}$ $\min ^{-1}$. For the trimethylsilyl derivative of NP isomers (NP-TMS), we selected the diagnostic ions 207 (target) and 221 and 193 (qualifiers); for the octylphenol derivative (OP-TMS), the diagnostic ions were 207 (target) and 278 and 208 (qualifiers); and for BPA, 357 (target) and 358 and 372 (qualifiers) were used. For the internal standard (363 $\mathrm{NP}^{13} \mathrm{C}_{6}$-TMS), the ions were 227 (target) and 269 and 298 (qualifiers). All chemicals used were obtained from Sigma-Aldrich, 4-Nonylphenol (\# 29, 085-8), octylphenol 99\%, bisphenol A 99\%, 4-(3,6-dimethyl-3-heptyl)phenol (ring- $\left.{ }^{13} \mathrm{C}_{6}\right)^{b}$ ([13C6]-363 NP \# 33575) and MSTFA, (\# 394866)].

\section{Genotoxicity assay}

Genotoxicity was assessed using the GreenScreen GC ${ }^{\mathrm{TM}}$ assay from Gentronix Ltd., which uses a DNA repair-competent strain of the yeast Saccharomyces cerevisiae. Basically, the reporter consisted of a fusion of the DNA damage-in-

Table 2. Trace metals $(\mu \mathrm{g} / \mathrm{g})$ obtained in sediments of the sampling points (mean value $\pm \mathrm{SE}$ ). Sampling points are ordered from the uppermost (OA) to the lowermost (S3) locations (see abbreviations in Table 1). Values in bold indicate the highest concentration for each metal. Metales traza $(\mu \mathrm{g} / \mathrm{g}$ ) obtenidos en los sedimentos de las localidades de muestreo (valores medios \pm SE). Los puntos de muestreo están ordenados desde el localizado a mayor altitud en la cuenca (OA) hasta el localizado a menor altitud (S3) (ver abreviaciones en la Tabla 1). Los valores en negrita indican las concentraciones más elevadas para cada metal.

\begin{tabular}{cccccccc}
\hline Metals & OA & CH & MU & RS & S1 & S2 & S3 \\
\hline $\mathrm{Ni}$ & $4.1 \pm 0.1$ & $17.0 \pm 0.3$ & $16.7 \pm 0.1$ & $12.0 \pm 0.3$ & $16.2 \pm 0.6$ & $15.5 \pm 0.7$ & $\mathbf{1 8 . 8} \pm \mathbf{0 . 1}$ \\
$\mathrm{Cr}$ & $9.3 \pm 0.2$ & $24.8 \pm 0.5$ & $22.8 \pm 5.8$ & $15.7 \pm 0.1$ & $26.4 \pm 1.6$ & $21.7 \pm 0.1$ & $\mathbf{3 5 . 4} \pm \mathbf{1 . 4}$ \\
$\mathrm{Cu}$ & $6.5 \pm 0.0$ & $15.4 \pm 0.8$ & $17.9 \pm 1.0$ & $7.5 \pm 1.1$ & $29.8 \pm 1.2$ & $15.5 \pm 0.8$ & $\mathbf{1 1 9 . 5} \pm \mathbf{1 1 . 0}$ \\
$\mathrm{Pb}$ & $4.5 \pm 0.9$ & $5.8 \pm 0.14$ & $11.6 \pm 3.1$ & $4.1 \pm 1.2$ & $13.2 \pm 0.6$ & $12.0 \pm 0.3$ & $\mathbf{2 4 . 4} \pm \mathbf{1 . 1}$ \\
$\mathrm{Zn}$ & $34.1 \pm 6.1$ & $29.6 \pm 0.1$ & $84.7 \pm 14.8$ & $31.2 \pm 2.1$ & $135.0 \pm 20.2$ & $56.4 \pm 0.7$ & $\mathbf{3 7 4 . 7} \pm \mathbf{3 . 0}$ \\
$\mathrm{Co}$ & $0.5 \pm 0.1$ & $\mathbf{7 . 1} \pm \mathbf{0 . 1}$ & $4.41 \pm 0.7$ & $2.7 \pm 0.1$ & $3.9 \pm 0.2$ & $4.3 \pm 0.1$ & $3.6 \pm 0.1$ \\
$\mathrm{As}$ & $0.0 \pm 0.0$ & $0.0 \pm 0.0$ & $\mathbf{4 . 7 3} \pm \mathbf{1 . 3}$ & $0.0 \pm 0.0$ & $0.0 \pm 0.0$ & $0.0 \pm 0.0$ & $0.0 \pm 0.0$ \\
$\mathrm{Cd}$ & $0.0 \pm 0.0$ & $0.0 \pm 0.0$ & $0.14 \pm 0.0$ & $0.1 \pm 0.0$ & $\mathbf{0 . 3} \pm \mathbf{0 . 1}$ & $0.0 \pm 0.0$ & $0.2 \pm 0.0$ \\
\hline
\end{tabular}


ducible promoter from an endogenous DNA repair gene, RAD54, with a gene encoding a yeastenhanced green fluorescent protein (yEGFP). RAD54 is known to be specifically up-regulated by the cells in response to DNA damage; thus, on exposure to a genotoxic agent, the cells become increasingly fluorescent as GFP accumulates. The protocol described by Cahill et al., (2004) has been previously reported for monitoring aquatic environments (García-Alonso et al., 2011). Cell density was quantified by optical absorbance (450 nm, data not shown). Methyl methanesulfonate (MMS, Sigma-Aldrich) was used as a genotoxic standard. Sediment samples were dried at $60{ }^{\circ} \mathrm{C} ; 200 \mathrm{mg}$ were re-suspended with $1 \mathrm{ml} 100 \%$ dimethyl sulfoxide (DMSO), vigorously vortexed 3 times for $5 \mathrm{~min}$ and centrifuged at $8000 \mathrm{~g}$. After incubation overnight in 6-well plates, fluorescence (excitation $485 \mathrm{~nm}$, emission $510 \mathrm{~nm}$ ) was monitored using a microplate reader (POLARstar OPTIMA, BMG Labtech, UK). The LEC (lowest effective concentration) in $\mathrm{g} \mathrm{ml}^{-1}$ is the lowest test concentration of sediment extract at which the significance threshold for genotoxicity is exceeded. The reciprocal of this variable (1/LEC) was considered for analysis to ensure an easier interpretation.

\section{Data analyses}

Correlations among the compounds, genotoxicities, OM and altitude were evaluated by Pearson correlation analysis. Pollutant concentrations and toxicological information about the sampling locations were analysed using a Principal Com- ponents Analysis (PCA) based on a correlation matrix. To achieve this, the FactoMineR package (Husson et al., 2014) for multivariate analysis was implemented. Because we considered variables in different units, they were scaled to unit variance. The number of retained dimensions in the PCA was determined by considering the percentage of variance these explained, with $75 \%$ as a reference.

\section{RESULTS}

The sampling sites are presented in Table $1 \mathrm{ac}$ cording to the ordination described for the Segura Basin and the sediment characterisation. In general, OA, the most upstream sampling point, showed the lowest levels of inorganic and organic pollutants, while the samples that were farthest downstream (Segura River S3) presented the highest values for almost all of the pollutants analysed (Tables 2 and 3).

\section{Metals and EDC contaminants}

$\mathrm{Zn}, \mathrm{Cu}, \mathrm{Cr}, \mathrm{Ni}$ and $\mathrm{Pb}$, which are metals that reflect anthropic activities, appeared at higher levels in the downstream sampling points (Table 2). They appeared in the following concentration order: $\mathrm{Zn}>\mathrm{Cu}>\mathrm{Cr}>\mathrm{Ni}>\mathrm{Pb}>\mathrm{Co}>\mathrm{As}>\mathrm{Cd}$. The five first metals were positively correlated (Table 4), indicating similar local fates of accumulation in the basin. In contrast, As was not correlated in its distribution with any other compound, while Co was only positively correlated with $\mathrm{Ni}$ among the metals. Interestingly, with the excep-

Table 3. EDCs (ng/g d.w.) obtained in sediments of the sampling points (mean values \pm SE). Sampling points are ordered from the uppermost (OA) to the lowermost (S3) locations (see abbreviations in Table 1). Nonylphenol (NP), Octylphenol (OP) and Bisphenol A (BPA). Values in bold indicate the highest concentrations. ECDs (ng/g peso seco) obtenidos en los sedimentos de las localidades de muestreo (valores medios \pm SE). Las localidades están ordenadas desde la localizada a más altitud en la cuenca (OA) hasta la más baja (S3) (ver abreviaciones en la Tabla 1). Nonilfenol (NP), Octilfenol (OP) y Bisfenol A (BPA). Los valores en negrita indican las concentraciones más elevadas para cada metal.

\begin{tabular}{cccccccc}
\hline EDC & OA & CH & MU & RS & S1 & S2 & S3 \\
\hline NP & $6.0 \pm 1.8$ & $10.8 \pm 2.0$ & $15.4 \pm 3.4$ & $13.5 \pm 2.3$ & $22.4 \pm 5.3$ & $96.0 \pm 9.7$ & $\mathbf{1 3 3 . 3} \pm \mathbf{1 8 . 1}$ \\
OP & $2.0 \pm 0.3$ & $7.8 \pm 0.3$ & $3.4 \pm 1.1$ & $6.1 \pm 1.0$ & $22.5 \pm 0.9$ & $10.4 \pm 1.1$ & $\mathbf{2 3 . 3} \pm \mathbf{3 . 0}$ \\
BPA & $2.3 \pm 0.5$ & $2.0 \pm 0.1$ & $5.9 \pm 2.1$ & $6.1 \pm 2.3$ & $17.8 \pm 4.0$ & $20.8 \pm 2.3$ & $\mathbf{3 5 . 4} \pm \mathbf{6 . 3}$ \\
\hline
\end{tabular}




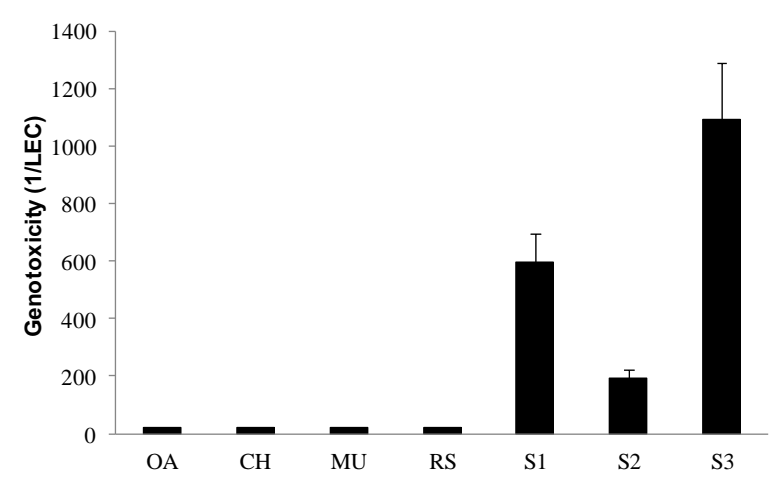

Figure 2. Genotoxicity for each sampling station. Values are presented as the reciprocal of the lowest effective concentration (1/LEC). Sampling stations are ordered from the uppermost (OA) to the lowermost (S3) locations (see abbreviations in Table 1). $95 \%$ confidence intervals are shown. Genotoxicidad para cada una de las estaciones de muestreo. Los valores se presentan como la inversa de la mínima concentración efectiva (1/LEC). Las estaciones de muestreo están ordenadas desde la localizada a mayor altitud en la cuenca (OA) hasta la localizada a menor altitud (S3) (ver abreviaciones en la Tabla 1). Se presentan los intervalos de confianza al $95 \%$.

tion of $\mathrm{Co}$ and $\mathrm{Ni}$, none of the metals analysed in this study were significantly correlated with organic matter (Table 4).
The EDCs with estrogenic activity considered in the study showed higher concentrations in the main river at the S3 location (Table 3). NP, a surfactant used in agricultural, domestic and industrial activities in the past, was the most abundant. Similar to metals, the EDCs were not significantly correlated with organic matter (Table 4).

\section{Sediment genotoxicity}

The values of sediment toxicity were higher at downstream than upstream locations (Fig. 2). Genotoxicity (1/LEC) clearly increased towards low-altitude sites, as would be expected because of discharges from cities and industrial activities in the river plain areas. The lowest genotoxicities were found in pristine locations such as OA (Fig. 2), while the zone with the highest genotoxicity was S3, which is located before the river reaches the Mediterranean Sea. No significant correlation was found between genotoxicity and organic matter (Table 4). All EDCs and metals (with the exception of Co and As) were significantly and positively correlated with genotoxicity (Table 4).

Table 4. Pearson correlation coefficients between inorganic and organic chemicals found in sediments along the Segura River Basin. Genotoxicity (Genot), organic matter (OM), Nonylphenol (NP), Octylphenol (OP) and Bisphenol A (BPA). Values in bold indicate significant correlations $(p<0.05)$. Coeficientes de correlación de Pearson entre contaminantes inorgánicos y orgánicos presentes en sedimentos de la cuenca del Río Segura. Genotoxicidad (Genot), contenido materia orgánica (OM), Nonilfenol (NP), Octilfenol (OP) y Bisfenol A (BPA). Los valores en negrita indican correlaciones significativas ( $\mathrm{p}<0.05)$.

\begin{tabular}{|c|c|c|c|c|c|c|c|c|c|c|c|c|c|}
\hline & Genot & $\mathrm{Ni}$ & $\mathrm{Cr}$ & $\mathrm{Cu}$ & $\mathrm{Pb}$ & $\mathrm{Zn}$ & Co & As & $\mathrm{Cd}$ & $\mathrm{NP}$ & OP & BPA & $\mathrm{OM}$ \\
\hline Genot & & & & & & & & & & & & & \\
\hline $\mathrm{Ni}$ & 0.48 & & & & & & & & & & & & \\
\hline $\mathrm{Cr}$ & 0.76 & 0.86 & & & & & & & & & & & \\
\hline $\mathrm{Cu}$ & 0.91 & 0.49 & 0.77 & & & & & & & & & & \\
\hline $\mathrm{Pb}$ & 0.88 & 0.65 & 0.86 & 0.90 & & & & & & & & & \\
\hline $\mathrm{Zn}$ & 0.94 & 0.50 & 0.80 & 0.98 & 0.94 & & & & & & & & \\
\hline Co & 0.01 & 0.75 & 0.53 & 0.05 & 0.13 & 0.00 & & & & & & & \\
\hline As & -0.26 & 0.21 & 0.01 & -0.13 & 0.02 & -0.09 & 0.13 & & & & & & \\
\hline $\mathrm{Cd}$ & 0.71 & 0.50 & 0.55 & 0.48 & 0.71 & 0.58 & -0.02 & 0.05 & & & & & \\
\hline $\mathrm{NP}$ & 0.73 & 0.51 & 0.64 & 0.78 & 0.84 & 0.76 & 0.11 & -0.23 & 0.52 & & & & \\
\hline $\mathrm{OP}$ & 0.76 & 0.49 & 0.71 & 0.92 & 0.77 & 0.85 & 0.17 & -0.24 & 0.26 & 0.84 & & & \\
\hline BPA & 0.82 & 0.50 & 0.65 & 0.77 & 0.85 & 0.77 & 0.05 & -0.27 & 0.71 & 0.94 & 0.76 & & \\
\hline $\mathrm{OM}$ & 0.15 & -0.70 & -0.42 & 0.15 & -0.00 & 0.15 & -0.89 & -0.39 & -0.04 & 0.15 & 0.10 & 0.15 & \\
\hline
\end{tabular}




\section{Multivariate analyses}

As a result of the PCA, only 2 dimensions were retained, which explained $80.44 \%$ of the variance. Figure 3 shows stations OA and S3 in opposite positions; these stations make an important contribution to dimension 1 (Table 5), which explains the majority of the variance $(58.83 \%)$. This dimension was mainly determined by $\mathrm{Cr}, \mathrm{Cu}, \mathrm{Pb}$, $\mathrm{Zn}, \mathrm{NP}, \mathrm{BPA}$ and genotoxicity (1/LEC, Table 5). Dimension 2 was principally constructed by the contributions of stations $\mathrm{OA}, \mathrm{CH}$ and MU (Table 5). $\mathrm{Ni}$, Co and $\mathrm{OM}$ were the main variables that determined dimension 2 (Table 5) and were responsible for the distribution of the sites related to this dimension in the PCA (Fig. 3).

\section{DISCUSSION}

The quantification of toxic compounds, their relative toxicities and the environmental factors affecting contamination-toxicity relationships are crucial for the evaluation, regulation and management of aquatic systems. Environmental gradients in aquatic systems determine biotic and abiotic processes and, consequently, the distribution, accumulation and degradation of products derived from human activities (Arellano et al. 2014). In this sense, environmental conditions determine the toxicity levels of contaminants and, therefore, the risk to which organisms are subjected (García-Alonso et al., 2011). We tested these aspects here using an integrative approach, analysing the relationships between contaminants and toxicities in a set of sediment samples covering an upstream-downstream gradient in the Segura Basin.

Trace metals accumulate in sediments through different partitioning processes (Luoma \& Rainbow, 2008) depending on the inherent properties of the metals and the environment. As expected, metal concentrations showed a clear gradient along the basin, and their concentrations were negatively correlated with altitude. In terms of accumulation, the results indicate that all metals behave in a similar way along the basin. In fact, most of the metals reached their highest con-
Table 5. Contribution percentages of sampling sites and environmental and toxicological variables to the dimensions considered in the Principal Component Analysis. Values in bold indicate contributions higher than $10 \%$. Sampling sites are ordered from the uppermost (OA) to the lower most (S3) locations (see abbreviations in Table 1). Nonylphenol (NP), Octylphenol (OP) and Bisphenol A (BPA), organic matter (OM). Contribución porcentual de las localidades de muestreo, las variables ambientales y toxicológicas a las dimensiones consideradas en el Análisis de Componentes Principales. Los valores en negrita indican contribuciones mayores al 10\%. Los sitios de muestreo están ordenados desde el localizado a más altitud en la cuenca (OA) hasta el localizado a menor altitud (S3) (ver abreviaciones en la Tabla 1).

\begin{tabular}{ccc}
\hline Site & Dimension 1 & Dimension 2 \\
\hline OA & $\mathbf{1 9 . 3 4}$ & $\mathbf{4 5 . 6 6}$ \\
CH & 3.41 & $\mathbf{2 4 . 6 3}$ \\
MU & 1.47 & $\mathbf{2 0 . 8 0}$ \\
RS & 7.55 & 1.81 \\
S1 & 1.20 & 0.47 \\
S2 & 0.84 & 0.55 \\
S3 & $\mathbf{6 6 . 1 7}$ & 6.06 \\
\hline Variable & Dimension & Dimension 2 \\
\hline Ni & 6.26 & $\mathbf{1 6 . 9 0}$ \\
Cr & $\mathbf{1 0 . 3 0}$ & 5.21 \\
Cu & $\mathbf{1 1 . 4 0}$ & 1.07 \\
Pb & $\mathbf{1 2 . 2 1}$ & 0.01 \\
Zn & $\mathbf{1 1 . 5 6}$ & 1.15 \\
Co & 0.63 & $\mathbf{2 7 . 9 3}$ \\
As & 0.22 & 8.28 \\
Cd & 5.92 & 0.00 \\
OM & 0.02 & $\mathbf{3 4 . 7 3}$ \\
NP & $\mathbf{1 0 . 0 4}$ & 1.04 \\
OP & 9.78 & 0.60 \\
BPA & $\mathbf{1 0 . 5 2}$ & 1.42 \\
Genotoxicity & $\mathbf{1 1 . 1 4}$ & 1.62 \\
\hline
\end{tabular}

centrations in the sediments of station S3. Station S1, upstream from Murcia city, presented the second highest levels of anthropic impact markers such as $\mathrm{Cr}, \mathrm{Cu}, \mathrm{Pb}, \mathrm{Zn}$, and $\mathrm{Cd}$. Interestingly, the same pattern of genotoxicity was observed, indicating that metals with genotoxic properties might be the source of the toxic sediment properties. $\mathrm{Cu}, \mathrm{Cr}, \mathrm{Pb}$ and $\mathrm{Zn}$ might reach levels that are toxic for the aquatic community, although their bioavailability and potential toxicity depend on the partitioning and speciation of these elements (see Luoma \& Rainbow, 2008). The most remarkable, due to its potential toxicity, was $\mathrm{Cu}$, 
with an average concentration of $119 \mu \mathrm{g} / \mathrm{g}$ of dry sediment at S3 (Table 2).

In the case of $\mathrm{Ni}$, $\mathrm{Co}$ and $\mathrm{Cr}$, we found similar levels along the basin, indicating a natural source of these elements related to lithologic composition, as described by Prego et al. (2013) for the NW Spanish Mediterranean coast. $\mathrm{Pb}$ was observed at relatively low levels and did not reach the toxic values suggested by Luoma \& Rainbow (2008) for aquatic sediments. However, $\mathrm{Cu}$ at the most downstream location (downstream from Orihuela city) showed a relatively high level $(119 \mu \mathrm{g} / \mathrm{g})$, in accord with Luoma \& Rainbow (2008). Zn appears with elevated concentrations at station S3, which can be catalogued as toxic because the values overcame the probable effect level (PEL) for freshwater ecosystems ( $315 \mu \mathrm{g} / \mathrm{g}$, Canadian Council of Ministers of the Environment, 1995).
We found a gradient of xeno-estrogens towards the mouth of the Segura River. Sediment samples showed the presence of OP, NP, and BPA, which can potentially affect aquatic populations. Upstream levels were very low, indicating clean environments compared to the polluted main river (Segura). Stations S2 and S3 showed potential critical levels of NP according to the WFD and based on Brix et al. (2010). Extremely low levels of xeno-estrogens in water (5-6 ng/L) induced feminisation and finally local extinction in fish populations (Kidd et al., 2007). At low concentrations, EDCs can accumulate within the tissues over extended periods of time and can cause sub-lethal effects such as oxidative stress by depleting glutathione levels (Ayoola $e t$ al., 2011). At levels higher than $660 \mu \mathrm{g} / \mathrm{L}$, the concentration becomes lethal for fishes (Uguz et al., 2003a). Due to their hydrophobicity, these

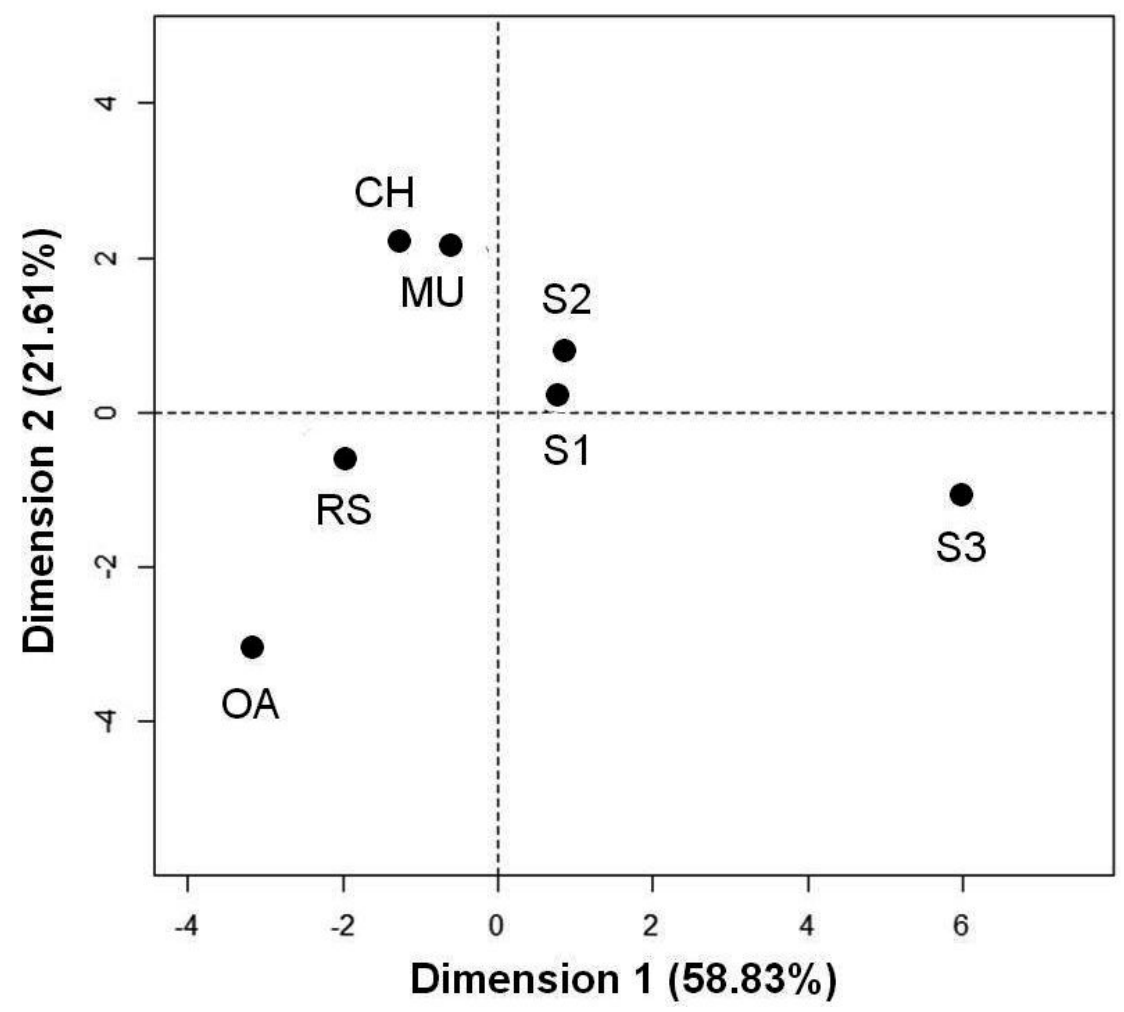

Figure 3. Principal Component Analysis (PCA) and positions of the sampling locations according to their scores. Percentages of the variance explained by each component are enclosed in parentheses. See abbreviations in Table 1. Análisis de Componentes Principales (ACP) y la localización de los puntos de muestreo en la dispersión de datos. El porcentaje de la varianza explicada por cada componente se presenta entre paréntesis. Ver abreviaciones en la Tabla 1. 
EDCs accumulate in the sediment instead of in the water column, in contrast to a wide range of toxic organic compounds. Sediment concentration is therefore a more accurate way to determine the presence of these compounds. Xenoestrogens have demonstrated sub-lethal toxic effects at environmentally realistic concentrations (0.01-10.0 $\mu \mathrm{g} / \mathrm{L}$; Zoller, 2008). In this work, the levels of NP were higher than those of $\mathrm{OP}$ and BPA as commonly described in literature (Uguz et al., 2003b, Fu et al., 2007). This difference is due to the release of nonylphenol polyethoxylates, which degrade to the more persistent NP, thus maintaining its toxicity.

Neither the metals (except $\mathrm{Ni}$ and $\mathrm{Co}$ ) nor the EDCs analysed were correlated with organic matter along the Segura basin, although a clear increase in organic matter occurs downstream in the main river stations. The lack of relationship between the pollutants and organic matter might be due to the relatively pristine tributaries, which showed a high percentage of organic matter in the sediment and a low level of pollutants.

Genotoxicity was low at upstream locations and increased downstream. The sampling site $\mathrm{OA}$, at the headwaters of Segura Basin, is a small creek with low eutrophication and hypo-salinity. It can be considered the most pristine location in this study. In contrast, downstream of Orihuela city, the sediments collected at the S3 points were severely impacted and showed the most polluted conditions in this study. These two points also marked the extremes of the pollution gradient represented in the PCA. This pattern reflects the accumulation of contaminants towards the mouth of the river as well as the increased human population and agricultural and industrial activities in the plain regions. Although, agriculture activities might discharge high inputs of contaminants in upstream areas of the basin, transport downstream could determine the distribution and fate of pollutants along the basin.

Due to the complex mixtures of sediments, several contaminants commonly appear in polluted areas. In this sense, the genotoxic effect is an integrative response to pollutants. Further studies are required to unravel the complex sediment toxicities. The fact that we quantified con- centrations of inorganic and organic pollutants with some well-known genotoxic and carcinogenic properties notwithstanding, other potential contaminants and toxicities might be occurring in the Segura Basin. Nevertheless, our results clearly reflect the quality condition of the sediments in relation to their position in the basin, even when some sampling points, such as the $\mathrm{CH}$ and MU streams, contain higher concentrations of contaminants than RS, which is a tributary at a lower altitude. It is worth noting that MU is strongly affected by human activities.

The results obtained describe the main pollution trends in the Segura Basin. The conservation status of the tributaries of the Segura Basin is a relevant issue for achieving a good ecological status, taking into account the Water Framework Directives (WFD) requirements for the correct management plans of European rivers.

\section{ACKNOWLEDGEMENTS}

We are grateful for assistance with the analytical procedures from Maggy Harley, Department of Biological Sciences, and Robert Knight, Department of Chemistry, University of Hull. We thank Mar Torralva and Ana Ruiz for help in field and relief works, Department of Zoology, Universidad de Murcia. Part of the project was funded by LIFE Nature 2004 NAT/ES/000035 project.

\section{REFERENCES}

ARELLANO, L., J. O. GRIMALT, P. FERNÁNDEZ, J. F. LOPEZ, U. NICKUS, H. THIES. 2014. Persistent organic pollutant accumulation in seasonal snow along an altitudinal gradient in the Tyrolean Alps. Environmental Science and Pollution Research. in press 10.1007/s11356-014-3196-x

AYOOLA, J. A. O., J. GARCÍA-ALONSO \& J. D. HARDEGE. 2011. Glutathione-S-transferase in Nereis succinea (Polychaeta) and its induction by xeno-estrogen. Environmental Toxicology, 26: 559-565.

BELMAR, O., J. VELASCO, F. MARTÍNEZ-CAPEL \& A. A. MARÍN. 2010. Natural flow regime, degree of alteration and environmental flows in 
the Mula stream (Segura River basin, SE Spain). Limnetica, 29: 353-368.

BELMAR, O., J. VELASCO \& F. MARTÍNEZ-CAPEL. 2011. Hydrological classification of natural flow regimes to support environmental flow assessments in intensively regulated Mediterranean rivers, Segura River basin (Spain). Environmental Management, 47: 992-1004.

BONADA, N., N. PRAT, A. MUNNÉ, M. RIERADEVALL, J. ALBA-TERCEDOR, M. ÁLVAREZ, J. AVILÉS, J. CASAS, P. JÁIMEZ-CUÉLLAR, A. MELLADO, G. MOYÀ, I. PARDO, S. ROBLES, G. RAMON, M. L. SUÁREZ, M. TORO, M. R. VIDAL-ABARCA, S. VIVAS \& C. ZAMORA-MUÑOZ. 2002. Ensayo de una tipología de las cuencas mediterráneas del proyecto GUADALMED siguiendo las directrices de la directiva marco del agua. Limnetica, 21: 77-98.

BRIX, R., C. POSTIGO, S. GONZÁLEZ, M. VILLAGRASA, A. NAVARRO, M. KUSTER, M. J. DE ALDA, D. BARCELÓ. 2010. Analysis and occurrence of alkylphenolic compounds and estrogens in aEuropean river basin and an evaluation of their importance as prioritypollutants. Analytical and Bioanalytical Chemistry, 396: 1301-9.

CAHILL, P. A., A. W. KNIGHT, N. BILLINTON,M. G. BARKER,L. WALSH,P. O. KEENAN, C. V.WILLIAMS, D. J. TWEATS \& R. M. WALMSLEY. 2004. The GreenScreen genotoxicity assay: a screening validation. Mutagenesis, 19: 105-119.

Canadian Council of Ministers of the Environment (CCME). 1995. Protocol for the derivation of $\mathrm{Ca}$ nadian sediment quality guidelines for the protection of aquatic life. CCME EPC-98E. Prepared by Environment Canada, Guidelines Division, Technical Secretariat of the CCME Task Group on Water Quality Guidelines, Ottawa.

COOPER, R. L. \& R. J. KAVLOCK. 1997. Endocrine disrupters and reproductive development: a weight-of-evidence overview. Journal of Endocrinology, 152: 159-166.

FU, M., Z. LI \& H. GAO. 2007. Distribution characteristics of nonylphenol in Jiaozhou Bay of Qingdao and its adjacent rivers. Chemosphere, 69: 1009-1016.

GARCÍA-ALONSO, J., G. M. GREENWAY, A. MUNSHI, J. C. GÓMEZ,K. MAZIK, A. W. KNIGHT, J. D. HARDEGE \& M. ELLIOTT. 2011. Biological responses to contaminants in estuaries: disentangling complex relationships. Marine Environmental Research, 71: 295-303.
GÓMEZ, R., I. HURTADO, M. L. SUÁREZ \& M. R. VIDAL-ABARCA. 2005. Ramblas in southeast Spain: threatened and valuable ecosystems. Aquatic Conservation: Marine and Freshwater Ecosystems, 15: 387-402.

HUSSON, F., J. JOSSE, S. LE \& J. MAZET. 2014. FactoMineR: Multivariate exploratory data analysis and data mining with $\mathrm{R}$. $\mathrm{R}$ package version 1.26. http://CRAN.R-project.org/package=Facto MineR.

JANEX-HABIBI, M. L., A. HUYARD, M. ESPERANZA \& A. BRUCHET. 2009. Reduction of endocrine disruption emissions in the environment: The benefit of wastewater treatment. Water Research, 43: 1565-1576.

KIDD, K. A., P. J. BLANCHFIELD, K. H. MILLS, V. P. PALACE, R. E. EVANS, J. M. LAZORCHAK \& R. W. FLICK. 2007. Collapse of a fish population after exposure to a synthetic estrogen. Proceeding of the national academy of sciences of USA, 104(21): 8897-8901.

LUOMA, S. N. \& P. S. RAINBOW. 2008. Metal Contamination in Aquatic Environments: Science and Lateral Management. Cambridge Univ, Cambridge (UK).

MELLADO, A., M. L. SUÁREZ, J. L. MORENO \& M. R. VIDAL-ABARCA. 2002. Aquatic macroinvertebrate biodiversity in the Segura River Basin (SE Spain). Verhandlungen der Internationalen Vereinigung fuer theoretische und angewandte Limnologie, 28: 1157-1162.

MELLADO, A., M. L. SUÁREZ, M. L. ALONSO \& M. R. VIDAL-ABARCA. 2008. Biological traits of stream macroinvertebrates from a semi-arid catchment: patterns along complex environmental gradients. Freshwater Biology, 53: 1-21.

NICE, H.E., D. MORRITT, M. CRANE \& M. THORNDYKE. 2003. Long-term and transgenerational effects of nonylphenol exposure at a key stage in the development of Crassostrea gigas. Possible endocrine disruption? Marine Ecology Progress Series, 256: 293-300.

NORRIS, D.O. \& J. A. CARR. 2006. Endocrine Disruptors: Biological Basis for Health Effects in Wildlife and Humans, Oxford University Press, New York.

PREGO, R., M. CAETANO, N. OSPINA-ALVAREZ, J. RAIMUNDO \& C. VALE. 2013. Basin-scale contributions of $\mathrm{Cr}$, Ni and Co from Ortegal Complex to the surrounding coastal environment ( $\mathrm{SW}$ 
Europe). Science of the Total Environment, 468: 495-504.

SÁNCHEZ-MONTOYA, M. M., T. PUNTÍ, M. L. SUÁREZ, M. R. VIDAL-ABARCA, M. RIERADEVALL, J. M. POQUET, C. ZAMORA-MUÑZ, S. ROBLES, M. ÁlVAREZ, J. ALBATERCEDOR, M. TORO, A. PUJANTE, A. MUNNÉ \& PRAT N. 2007. Concordance between ecotypes and macroinvertebrate assemblages in Mediterranean streams. Freshwater Biology, 52: 2240-2255.

UGUZ, C., M. ISCAN, A. ERGUVEN, B. ISGOR \& I. TOGAN. 2003a. The bioaccumulation of nonyphenol and its adverse effect on the liver of rainbow trout (Onchorynchusmykiss). Environmental Research, 92: 262-70.

UGUZ, C., I. TOGAN, Y. EROGLU, I. TABAK, M. ZENGIN, M. ISCAN. 2003b. Alkylphenol concentrations in two rivers of Turkey. Environmental Toxicology and Pharmacology, 14: 87-8.

VELASCO, J., A. MILLAN, M. R. VIDAL-ABRA-
CA, M. L. SUÁREZ, C. GUERRERO \& M. ORTEGA. 2003. Macrophytic, epipelic and epilithic primary production in a semiarid Mediterranean stream. Freshwater Biology, 48: 1408-1420.

VESES, O., R. Mosteo, M. P. ORMAD \& J. L. OVELLEIRO. 2014. Freshwater sediment quality in Spain. Environmental Earth Sciences, 1-13.

VIDAL-ABARCA, M. R. 1990. Los ríos de las cuencas áridas y semiáridas: Una perspectiva ecológica y de síntesis. Scientia gerundensis, 16: 219-228.

VIDAL-ABARCA, M. R., L. SUÁREZ, R. GÓMEZ, J. L. MORENO \& C. GUERRERO. 2002. Diel variations in physical and chemical paramenters in a semi-arid stream in Spain (Chícamo Stream). Verhandlungen der Internationalen Vereinigung fuer theoretische und angewandte Limnologie, 28: $1-5$.

ZOLLER, U. 2008. Distribution profiles of endocrine disrupting PAHs/APEOs in river sediments: Is there a potential ecotoxicological problem? Water Science and Technology, 57: 237-242. 